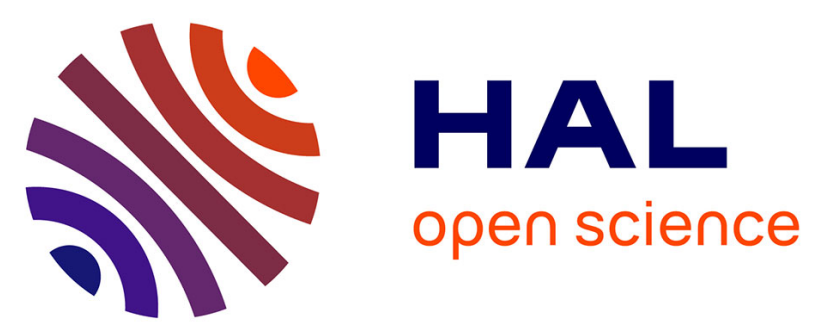

\title{
Sedimentary and water column processes in the Oyster Grounds: A potentially hypoxic region of the North Sea
}

K. Weston, L. Fernand, J. Nicholls, A. Marca-Bell, D. Mills, D. Sivyer, M. Trimmer

\section{- To cite this version:}

K. Weston, L. Fernand, J. Nicholls, A. Marca-Bell, D. Mills, et al.. Sedimentary and water column processes in the Oyster Grounds: A potentially hypoxic region of the North Sea. Marine Environmental Research, 2008, 65 (3), pp.235. 10.1016/j.marenvres.2007.11.002 . hal-00501927

\section{HAL Id: hal-00501927 https://hal.science/hal-00501927}

Submitted on 13 Jul 2010

HAL is a multi-disciplinary open access archive for the deposit and dissemination of scientific research documents, whether they are published or not. The documents may come from teaching and research institutions in France or abroad, or from public or private research centers.
L'archive ouverte pluridisciplinaire $\mathbf{H A L}$, est destinée au dépôt et à la diffusion de documents scientifiques de niveau recherche, publiés ou non, émanant des établissements d'enseignement et de recherche français ou étrangers, des laboratoires publics ou privés. 


\section{Accepted Manuscript}

Sedimentary and water column processes in the Oyster Grounds: A potentially hypoxic region of the North Sea

K. Weston, L. Fernand, J. Nicholls, A. Marca-Bell, D. Mills, D. Sivyer, M. Trimmer

PII:

S0141-1136(07)00132-8

DOI:

10.1016/j.marenvres.2007.11.002

Reference:

MERE 3153

To appear in:

Marine Environmental Research

Received Date:

18 July 2007

Revised Date:

5 November 2007

Accepted Date:

6 November 2007

Please cite this article as: Weston, K., Fernand, L., Nicholls, J., Marca-Bell, A., Mills, D., Sivyer, D., Trimmer, M., Sedimentary and water column processes in the Oyster Grounds: A potentially hypoxic region of the North Sea, Marine Environmental Research (2007), doi: 10.1016/j.marenvres.2007.11.002

This is a PDF file of an unedited manuscript that has been accepted for publication. As a service to our customers we are providing this early version of the manuscript. The manuscript will undergo copyediting, typesetting, and review of the resulting proof before it is published in its final form. Please note that during the production process errors may be discovered which could affect the content, and all legal disclaimers that apply to the journal pertain. 
1 Sedimentary and water column processes in the Oyster Grounds: A potentially

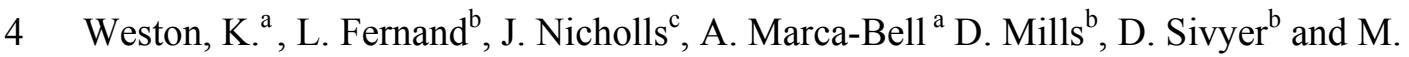

5 Trimmer $^{\mathrm{c}}$

6 aaboratory of Global Marine and Atmospheric Chemistry, School of Environmental

7 Sciences, University of East Anglia, Norwich, Norfolk, NR4 7TJ, U.K.

$8{ }^{\mathrm{b}}$ Centre for Environment, Fisheries and Aquaculture Science, Lowestoft, Suffolk,

$9 \quad$ NR33 OHT, U.K.

\section{Abstract}

The purpose of this research was to investigate the potential causes of low oxygen levels in the bottom water of the Oyster Grounds region of the shallow southern North Sea, an area which provides suitable conditions for low oxygen levels to develop. At the end of the summer stratified period, relevant biogeochemical processes were investigated using a combination of sedimentary and water column rate measurements. Phytoplankton nitrate and ammonium uptake was measured throughout the water column using ${ }^{15} \mathrm{~N}$ labelled isotopes and showed ammonium uptake dominated in the upper and bottom mixed layer with a maximum $294.4 \mathrm{~mol} \mathrm{~N}$ $\mathrm{m}^{-3} \mathrm{~h}^{-1}$. In the deep chlorophyll maximum at the thermocline, primary production was dominated by nitrate uptake, with an average of $35.0 \mathrm{~mol} \mathrm{~N} \mathrm{~m}^{-3} \mathrm{~h}^{-1}$, relative to ammonium uptake, with an average of $24.6 \mathrm{~mol} \mathrm{~N} \mathrm{~m}^{-3} \mathrm{~h}^{-1}$. This high relative nitrate uptake will in part result in exportable new production to the isolated bottom mixed layer and sediments, as opposed to regenerated ammonium driven uptake. This biomass export was indicated by significant benthic oxygen consumption rates in the stratified region (782-1275 $\mathrm{mol} \mathrm{O}_{2} \mathrm{~m}^{-2} \mathrm{~h}^{-1}$ ) long after the end of the spring bloom. The sediments were also an active net source of nitrate, ammonium, phosphate and

Corresponding author. Tel.: +44 1603 593398; fax: +44 1603591327

E-mail address: k.weston@uea.ac.uk (K. Weston) 
1 silicate into the bottom mixed layer of 4.4, 8.4, 2.3 and $68.8 \mathrm{~mol} \mathrm{~m}^{-2} \mathrm{~h}^{-1}$ respectively.

2 The export of new production within the thermocline to the bottom mixed layer and

3 the consequent sediment oxygen consumption in the isolated bottom mixed layer in

4 the Oyster Grounds are expected to have contributed to the low bottom water oxygen

5 concentrations of $2.07 \mathrm{mg} \mathrm{l}^{-1}\left(64.7 \mathrm{~mol} \mathrm{l}^{-1}\right)$ measured. The long stratified period

6 associated with this low oxygen is predicted to occur more regularly in the future and

7 continued monitoring of this ecologically important region is therefore essential if the

8 causes of these potentially damaging low oxygen levels are to be fully understood.

10 Keywords: shelf sea; North Sea; hypoxia; phytoplankton; primary production;

11 sediment chemistry

\section{Introduction}

In the coastal regions of shallow shelf seas environmental problems due to increased nutrient inputs have been a focus of research since the 1970s (Ryther and Dunstan, 1971). Problems due to these inputs are generally been studied in terms of either the effects on nutrient load and stoichiometry on the development of harmful algal blooms, e.g. Phaeocystis pouchetii in Dutch coastal waters (Peperzak, 2003), or the development of low oxygen bottom water, e.g. the 'dead zone' in the Gulf of Mexico (Rabalais et al., 2002). The latter is caused by the decomposition of increased primary production due to excess nutrient loading, i.e. eutrophication, in bottom mixed layer of the stratified water column with consequent oxygen consumption during remineralisation. This low oxygen concentration may affect the fauna living in the bottom water or in the sediments, e.g. demersal fish migration (Baden et al., 1990). In general these effects occur when dissolved oxygen concentrations drop below $2 \mathrm{mg} \mathrm{O}_{2}$ $1^{-1}$ or $62.5 \mathrm{~mol} \mathrm{l}^{-1}$ (Diaz, 2001) and is defined as hypoxia, with a complete absence of oxygen defined as anoxia (Diaz, 2001). There has been an increasing awareness of the occurrence of anthropogenically induced hypoxia in large areas of stratified and enclosed shelf seas, with substantial eutrophication-generated hypoxia also recorded

31 in the Baltic Sea ( $80,000 \mathrm{~km}^{2}$ ) (Conley et al., 2002) and the Black Sea ( $\left.20,000 \mathrm{~km}^{2}\right)$ 32 (Mee, 1992). 
1 The North Sea has had few published studies on hypoxia and these have focussed on 2 coastal waters i.e. German Bight (summarised in Colijn et al. (2002)). The North Sea

3 is a shelf sea surrounded by some of the most heavily industrialised nations of

4 northern Europe - mainly Great Britain, The Netherlands, Belgium and Germany, and has been shown to be strongly affected by anthropogenic activities evident from the occurrence of phenomena such as fisheries decline (Cook et al., 1997). It has a total area of $575,000 \mathrm{~km}^{2}$ with the majority of the southern North Sea being relatively shallow ( $\sim 40 \mathrm{~m}$ ) and well-mixed year round, and with summer stratified areas in the northern and central regions (Pingree et al., 1978) providing suitable physical conditions for low oxygen conditions to potentially develop. Previous studies off shore in the Oyster Grounds of the central stratified North Sea have shown decreasing bottom water oxygen concentrations (Postma and Rommets, 1984; Peeters et al., 1995 ) and although this region was not hypoxic, a recent report has also shown a trend of decreasing oxygen levels (Boers, 2005). The Oyster Grounds is also a temporary depocentre for sediments from the south-eastern North Sea (van Raaphorst et al., 1998) and the shallow topography and stratified nature of this region combined with potentially high nutrient concentrations and suitable sedimentary structure therefore provide near ideal conditions for low oxygen levels to develop. In addition,

19 a recent study in the central North Sea, Weston et al. (2005) also showed that the Deep Chlorophyll Maximum (DCM), present in similar stratified regions, to be a major source of new production (Dugdale and Goering, 1967) after the spring bloom and is therefore a potential source of biomass to the bottom waters.

The aim of this study was therefore to investigate sedimentary processes and production in the DCM of the Oyster Grounds in terms of its potential to reduce

26 column and sedimentary nutrient uptake rates in addition to hydrographic profiles 27 along transects using a towed undulating conductivity, temperature and depth sensor 28 (CTD) throughout the western Oyster Grounds region.

Figure 1

\section{Materials and methods}

\subsection{Study area}


2 The Oyster Grounds, also called Oyster Ground, is a large, roughly circular,

3 depression in the central North Sea with its centre at $54^{\circ} 30^{\prime} \mathrm{N}$ and $4^{\circ} 30^{\prime} \mathrm{E}$ (Fig. 1). It

4 reaches a maximum depth of more than $50 \mathrm{~m}$ at its centre and is bordered by the

5 shallower bathymetry of Dogger Bank, German Bight and Southern Bight. The

6 biologically enriched zone of the Frisian Front is situated on the southern edge of the

7 Oyster Grounds, in a sedimentary transitional zone where the seabed changes from the

8 sandy sediments of the Southern Bight to the muddy sediments of the Oyster Grounds

9 (Fig. 1). The Frisian Front is also in the transitional zone between the summer

10 stratified region of the deeper Oyster Grounds and the permanently well mixed

11 Southern Bight, as shown in figure 2, but is not a consistent feature in this region

12 (Baars et al., 1999). The onset of stratification in the central North Sea, of which the

13 Oyster Grounds is a part, is typically in May due to solar insolation and ends in mid-

14 October due to advective overturning from cooling (Tijssen and Wetsteyn, 1984).

\section{Figure 2}

In terms of marine nutrient input, at the southern edge of the Oyster Grounds there are three sources of nutrients which converge from the West: continental coastal water $(\mathrm{CCW})$; Channel water $(\mathrm{CW})$ and English coastal water (ECW). $\mathrm{CCW}$ is primarily composed of riverine input from the continental Rhine and Meuse rivers and is typically low in salinity and high in dissolved nutrients. $\mathrm{CW}$ is characterised by the highest salinity in the region. $\mathrm{ECW}$, made up primarily from riverine input from the Thames, Wash and Humber, is typically of salinity $33-34$ with elevated nutrients compared that of the Channel water, but significantly lower than $\mathrm{CCW}$. In the summer stratified region the main source of nutrients to the upper mixed layer is central North Sea water (CNSW), which originates from North Atlantic influx from the preceding winter. Due to the bowl-like nature of the Oyster Grounds the thermal stratification results in a bottom mixed layer which is broadly isolated from these external direct inputs during the stratified period.

31 Stratification and bottom water isolation provide the physical conditions that are necessary for low water oxygen to develop. The thermocline is also commonly within the euphotic zone, i.e. $>1 \%$ of surface irradiance, and results in the formation of a DCM. 


\subsection{Sampling strategy}

3

4

The sampling was carried out towards the end of the summer stratification in order that any potential oxygen depletion would be at its maximum and also when input from the DCM would be a source of biomass input to the bottom water. The cruise was carried out on R/V 'Endeavour' during $27^{\text {th }}$ September- $3^{\text {rd }}$ October 2003 with process sites in the western Oyster Grounds at which water column primary production, sedimentary denitrification, nutrient fluxes and oxygen consumption rates were measured. One process station was in the year round well-mixed Frisian Front (Station A) and 3 stations in the stratified region which formed the main focus of the research (Fig. 1). In addition to sampling at process stations, a series of transects provided measurement of physical, biological parameters at a high frequency in order to allow these process sites to be understood as a part of the broader oceanographic structure of the western region of the Oyster Grounds. An undulating CTD was used to measure temperature, salinity and fluorescence along the whole of these transects. Additional discrete stations along the transects were also sampled for a suite of chemical parameters and chlorophyll $a$.

\subsection{Physical oceanography}

Measurements of temperature and salinity were carried out along the 7 separate sampling transects (1-7; fig. 1) using both a towed oceanographic undulator fitted with a Falmouth Scientific Inc. Integrated CTD (Maine, USA) and CTD rosette also fitted with a Falmouth Scientific Inc. Integrated CTD (Maine, USA). The undulator enables profiling from $4 \mathrm{~m}$ below the sea surface to $3 \mathrm{~m}$ above the seabed. A comprehensive description of its use, calibrations and subsequent data analysis can be found in Brown et al. (1996). The CTD rosette also had a fluorometer and a photosynthetically active radiation (PAR) sensor (Li-cor, USA) attached. The fluorometer enabled the DCM to be identified and sampled directly using Niskin bottles (see section 2.4).

Salinity and density were calculated according to international standard procedures for seawater (UNESCO, 1981) and were determined to a standard deviation of 0.01 for salinity. 


\subsection{Chemical and biological survey}

3

4

Discrete samples were collected using a CTD rosette of 101 Niskin bottles along transects 1, 2 and 5 and at stations A-D (Fig. 1). Water samples were collected throughout the water column for measurement of chlorophyll $a$, phaeopigments and dissolved inorganic nutrients. For chlorophyll $a$, known volumes were filtered through Whatman glass fibre $(\mathrm{GF} / \mathrm{F})$ filters in triplicate. Pigments were extracted in acetone and analysis was carried out on board ship. A fluorometer (Turner Designs, USA) was used to measure extracted pigment fluorescence, and phaeopigments after acidification with $\mathrm{HCl}$, following the method described by Tett (1987). The fluorometer was calibrated using a solution of pure chlorophyll a (Sigma Chemical Co.) with concentration being determined spectrophotometrically. The \% error of chlorophyll $a$ analyses was $<2 \%$ relative to Turner certified reference material. Samples were also taken in triplicate and analysed on board for nitrate and nitrite (hereafter nitrate), ammonium, phosphate and silicate using a Skalar Autoanalyser (The Netherlands) according to Kirkwood (1996). The detection limit for nitrate, ammonium, phosphate and silicate analyses were $0.1 \mathrm{~mol}^{-1}, 0.2 \mathrm{~mol} \mathrm{l}^{-1}, 0.02 \mathrm{~mol} \mathrm{l}^{-1}$ and $0.1 \mathrm{~mol}^{-1}$ respectively. The $\%$ error for all nutrient analyses was $<5 \%$ relative to Ocean Scientific International (U.K.) standards.

At four CTD stations (A-D; fig. 1) water column profile and sediment samples were collected for further investigation using a CTD rosette. Light profiles were determined using the PAR sensor attached to the CTD rosette prior to sampling. Discrete water samples were collected using a CTD rosette of 101 Niskin bottles. Samples for water column phytoplankton nutrient uptake measurements were collected at 07-30 GMT. Water samples were collected at selected depths throughout the water column for measurement of chlorophyll $a$, nitrate, phosphate and silicate using an autoanalyser as above. At one station (B; fig. 1) water column dissolved oxygen concentrations were measured in both the upper mixed layer and bottom mixed layer in triplicate for $24 \mathrm{~h}$ at $6 \mathrm{~h}$ intervals. Samples were collected using the CTD rosette and analysed in triplicate using a Sensoren Instrumente Systeme (Germany) end point detector and Metrohm (Switzerland) Dosimat 665 Autotitrator according to (Williams and Jenkinson, 1982). Oxygen samples at other stations were lost. Ammonium was determined at depths 
1 sampled for nitrogen uptake measurements using a Jasco (Japan) fluorometer according to Holmes et al. (1999). Fluorometric determination of ammonium resulted in an improved detection limit compared to the colourimetric method with the autoanalyser ( $\sim 0.05 \mathrm{~mol}^{-1}$ compared to $0.5 \mathrm{~mol}^{-1}$, respectively). Intercalibration for these methods showed comparable results $>1 \mathrm{~mol} \mathrm{l}^{-1}$ for the two methods used (Results not shown). All nutrient and chlorophyll $a$ analyses were in triplicate.

\subsection{Water column nutrient uptake rates}

Samples were collected from the CTD casts for nitrate and ammonium uptake measurements at surface, $5 \mathrm{~m}, 15 \mathrm{~m}$ and bottom at station A (Fig. 1), at $5 \mathrm{~m}$, in the middle of upper mixed layer (UML), DCM associated with the thermocline and bottom mixed layer (BML) for stations $\mathrm{B}$ and $\mathrm{D}$, and at $5 \mathrm{~m}$, in the mid UML, and DCM for station C. The DCM was determined by inspection of the vertical profiles of temperature and chlorophyll $a$ fluorescence from a CTD cast. This profile was made immediately before the water sample collection. All samples were pre-screened through a $200 \mathrm{~m}$ mesh to remove mesozooplankton.

For nitrate and ammonium uptake rates measurements 11 seawater samples were transferred to 1.21 polycarbonate flasks and spiked with either ${ }^{15} \mathrm{~N}$-sodium nitrate (99 atom \%: Isotec, USA) or ${ }^{15} \mathrm{~N}$-ammonium sulphate (98 atom \%: Isotec, USA). Samples were enriched by an estimated $10 \%$ of in situ nutrient concentration, subject to a minimum addition of $0.1 \mathrm{~mol} \mathrm{~N}^{-1}$. Bottles from each depth were incubated in triplicate at corresponding \% surface light incident irradiance $( \pm 2 \%)$ respectively using neutral density filters (Lee, U.K.). For light irradiances $<0.1 \%$ samples were incubated in the dark. Samples were incubated in deck based incubators at surface seawater temperature using the online seawater supply for samples collected in the UML or in well-mixed station A. Where samples were taken at the thermocline or BML, samples were incubated in temperature controlled incubators to within $+/-2^{\circ} \mathrm{C}$ of in situ temperature. One 11 seawater sample for both nitrate and ammonium uptake from each depth was filtered immediately after isotope addition as a zero-time control. All other samples were incubated for $3 \mathrm{~h}$ immediately after ${ }^{15} \mathrm{~N}$-nitrate or ${ }^{15} \mathrm{~N}$ ammonium addition. After incubation, samples were filtered onto pre-combusted (4 h, $\left.400^{\circ} \mathrm{C}\right)$ Whatman $\mathrm{GF} / \mathrm{F}$ filters at low vacuum $(<50 \mathrm{~mm} \mathrm{Hg})$. All filters were dried 
1 immediately after filtration $\left(16 \mathrm{~h}, 40^{\circ} \mathrm{C}\right)$ and stored in clean Petri dishes at room temperature. Particulate nitrogen and atom $\% \mathrm{~N}$ of filtrate was determined using a

3 Europa Scientific (U.K.) 20-20 continuous flow isotope mass spectrometer online

4 with an ANCA elemental analyser. Nitrogen uptake rates were then calculated using

5 the models of Dugdale and Goering (1967).

\subsection{Sedimentary process measurements}

Sediment samples and overlying water at each site were collected using a NIOZ box 10 corer (NIOZ, The Netherlands), which was deployed $\sim 8$ times to collect sediment for sub-sampling. At each station 3 intact vertical sediment cores $(40 \mathrm{~cm}$ long x $10 \mathrm{~cm}$ i.d.) for sediment-water nutrient exchange (section 2.4.1) were taken and sealed at the bottom with bungs, an additional three cores $(50 \mathrm{~cm}$ long $x 9 \mathrm{~cm}$ i.d.) for oxygen uptake (section 2.4.2), and 8 small cores ( $25 \mathrm{~cm}$ long $x 3.4 \mathrm{~cm}$ i.d.) for denitrification experiments (section 2.4.3) were also taken from the box cores and sealed at the bottom with bungs.

\subsubsection{Sediment-water nutrient exchange}

The overlying water in each of the core tubes was supplemented with water collected by the CTD with Niskin bottles from near the seabed at the appropriate station to a final volume of $\sim 750 \mathrm{ml}$. The cores were immediately placed in a thermostatically controlled water bath at the temperature of the corresponding overlying water and allowed to re-equilibrate for $1 \mathrm{~h}$. The water overlying each core was gently aerated and stirred to prevent oxygen depletion. An identical clear plastic

26 tube was incubated with $\sim 750 \mathrm{ml}$ of site water as a control. After re-equilibration, sub-samples of the overlying water were removed by syringe at hourly intervals for

28 the first $2-5 \mathrm{~h}$ then two further samples were taken at 8 and $12 \mathrm{~h}$. All subsamples were

29 immediately filtered through a $0.2 \mathrm{~m}$ filter (Sartorius, Germany) prior to nutrient

30 analysis as above. Nutrient concentrations were corrected for the volume of overlying

31 water. The flux between the overlying water and sediment of each core was calculated

32 from the slope of the linear portion of the graph $(\mathrm{P}<0.05)$ and converted to a flux.

33 The error on the nutrient flux associated with each individual core was defined by the 
1 standard deviation of the linear regression analysis used to define the linear portion of

2 the graph and was $<10 \%$.

3

4

5

6

\subsubsection{Oxygen uptake rates}

The three oxygen uptake cores were stored completely submerged in aerated site water at in situ temperatures for 4 hours for re-equilibration. These were subsequently capped and completely water filled to exclude all air bubbles. The water column in each core was stirred with an induction motor driving a magnetic follower (Rank Brothers, U.K.) and a $20 \mathrm{ml}$ mid-water column sample was then drawn off into a gas tight syringe and gently transferred into a gas tight $12 \mathrm{ml}$ Exetainer (Labco, UK) and fixed for Winkler measurement of dissolved oxygen. Sediment-water oxygen uptake rates were measured using dissolved oxygen electrodes (Strathkelvin Instruments Ltd., U.K.) and data logging equipment as described by Nedwell and Trimmer (1996). Oxygen uptake was recorded continuously for the $3 \mathrm{~h}$ incubation period.

\subsubsection{Denitrification rates}

Rates of denitrification, both coupled denitrification $\left(\mathrm{D}_{\mathrm{n}}\right)$ and denitrification of nitrate exchanged from the water column $\left(D_{w}\right)$ were measured in the smaller cores using the isotope pairing technique according to (Nielsen, 1992). ${ }^{15} \mathrm{~N}$ labelled $\mathrm{Na}^{15} \mathrm{NO}_{3}$ was added (nominal concentration $25 \mu \mathrm{M}$ ) to the water column of four replicate cores. There were also four reference cores to which no isotope was added.

The water was gently stirred before a zero-time water sample for nutrient analysis was taken and the core sealed using a rubber bung with a built-in magnetic follower. Care was taken to avoid any air bubbles in the core. The cores were then incubated at in situ temperature with stirring for $6 \mathrm{~h}$. At the end of this time a two-way valve was used to simultaneously introduce a nitrogen gas headspace $(6 \mathrm{ml})$ and withdraw a $\mathrm{T}_{\mathrm{f}}$ nutrient sample $(6 \mathrm{ml})$. Nutrient samples were filtered $(0.2 \mu \mathrm{m}$ Minisart Plus, Sartorius, Germany) and then frozen at $-20^{\circ} \mathrm{C}$. The cores were then vigorously shaken and placed on rollers for $10 \mathrm{~min}$ before a sample of the headspace was taken $(4 \mathrm{ml})$ and transferred through a septum to an inverted water filled $12 \mathrm{ml}$ vial (Labco, U.K.), with water venting to atmosphere through a small bore needle. Mass charge ratios for ${ }^{28} \mathrm{~N}_{2},{ }^{29} \mathrm{~N}_{2}$ and ${ }^{30} \mathrm{~N}_{2}$ were analysed on an elemental analyser interfaced using a 
1 continuous flow isotope ratio mass spectrometer (Flash EA 1112, Thermo-Finnigan,

2 Germany). Denitrification rates were calculated according to Nielsen (1992).

3

$4 \quad$ Figure 3

5

6

7

8

9

10

\section{Results}

\section{Figure 4}

\subsection{Physical oceanography}

The section (Fig. 3; section a) from the top of the Dogger Bank through station B to station A showed three regions; well-mixed on the Dogger Bank $(0-15 \mathrm{~km})$, stratified between $20-120 \mathrm{~km}$, and well mixed inshore to the Dutch coast. The depth of the bottom mixed layer (BML) in the stratified region was variable up to a maximum of $15 \mathrm{~m}$ above the seabed, while the upper mixed layer extended to $25-35$ $\mathrm{m}$ depth. At the thermocline temperature gradients were strong with $\sim 4^{\circ} \mathrm{C}$ change over $3 \mathrm{~m}$ vertically. Site A was situated in the well-mixed waters of the Frisian front, and was the co-location meeting of the easterly extent of English coastal water, English Channel water and fresher continental coastal water as evident from the salinity (not shown) and density (Fig. 3). Section b (Fig. 3), which is orientated south west - north east, showed well-mixed water to the south and the stratified region from $90 \mathrm{~km}$ to the northern end of the section. In combination with section c (Fig. 3) and fig. 4 , showing bottom water density, there was a clear area of isolated bottom water at the seabed of the Oyster Grounds region.

\subsection{Water column nutrient, chlorophyll a and dissolved oxygen}

In the surface waters of the CTD transect from the stratified Oyster Grounds (leg 2 and 5; fig. 1) to the well-mixed Frisian front (leg 1; fig.1) low concentrations $(\sim 0.1-$ $0.5 \mathrm{~mol} \mathrm{l}^{-1}$ ) for nitrate, phosphate and ammonium were measured (Fig. 5). For silicate, relatively higher concentrations were measured in surface waters up to a maximum of $4.6 \mathrm{~mol} \mathrm{l}^{-1}$ (Fig. 5). 
Figure 5

3

4

In the stratified region, all nutrient concentrations generally decreased to below detection limits in the upper mixed layer. Nutrient concentrations increased both at the thermocline and in the BML to maximum concentrations of nitrate $\left(2.76 \mathrm{~mol} \mathrm{l}^{-1}\right)$, phosphate $\left(0.78 \mathrm{~mol} \mathrm{l}^{-1}\right)$, silicate $\left(16.07 \mathrm{~mol} \mathrm{l}^{-1}\right)$ and ammonium $\left(3.60 \mathrm{~mol} \mathrm{l}^{-1}\right)$. In the stratified region chlorophyll $a$ concentration was low or below detection limit in the upper mixed layer and then increased at and below the thermocline $\left(1-1.5 \mathrm{~g}^{-1}\right)$. In the well mixed regions chlorophyll $a$ concentrations ranged from $\sim 2 \mathrm{~g} \mathrm{l}^{-1}$ in the deeper water to $5.8 \mathrm{~g} \mathrm{l}^{-1}$ in the shallow water at the southernmost end of transect 1 . Although only transects 2 and 5 are shown they were indicative of the conditions for all transects

Water column oxygen concentration measurements were only carried out at station B with average concentrations over a $24 \mathrm{~h}$ period of $2.07 \mathrm{mg}^{-1}\left(64.7 \mathrm{~mol}^{-1}\right)$ and 5.43 $\mathrm{mg}^{-1}\left(169.6 \mathrm{~mol}^{-1}\right)$ in the bottom mixed layer $(44 \mathrm{~m})$ and upper mixed layer $(2 \mathrm{~m})$ respectively.

\subsection{Sedimentary processes}

Significant rates of benthic oxygen uptake were measured at all sites $(\mathrm{P}<0.05)$. Rates of oxygen uptake (Table 1) ranged from $524 \mu \mathrm{mol} \mathrm{O} \mathrm{O}^{-2} \mathrm{~h}^{-1}$ at station A to $1275 \mu \mathrm{mol} \mathrm{O}_{2} \mathrm{~m}^{-2} \mathrm{~h}^{-1}$ at station D. There were significant differences among the sites (One-way ANOVA, $\mathrm{F}=5.87$, d.f. $=11, \mathrm{P}=0.020$ ), station A had significantly lower rates of uptake than station D (Tukey's post hoc test).

Rates of coupled nitrification-denitrification $\left(D_{n}\right)$ were not significantly different among the sites (One-way ANOVA, d.f. $=14, \mathrm{~F}=1.031, \mathrm{P}=0.416$ ) and ranged from $2.6 \mu \mathrm{mol} \mathrm{N} \mathrm{m} \mathrm{N}^{-2}$ at station $\mathrm{C}$ to $3.4 \mu \mathrm{mol} \mathrm{N} \mathrm{m} \mathrm{N}^{-2}$ at station B (Table 1).

Denitrification supported by nitrate exchange from the overlying water $\left(D_{w}\right)$ was minimal (less than $1 \mu \mathrm{mol} \mathrm{N} \mathrm{m} \mathrm{N}^{-2}$ ) at all sites. A one way ANOVA showed a significantly higher rate of $\mathrm{D}_{\mathrm{w}}$ at station $\mathrm{A}$ at the Frisian Front (d.f. $=15, \mathrm{~F}=8.641, \mathrm{P}$ $=0.003)$ (Tukey's post hoc test). 
1 Sedimentary fluxes of nutrients from the sediment to the water column were highest

2 at station $\mathrm{C}$ for nitrate $\left(7.9 \mathrm{~mol} \mathrm{~m}^{-2} \mathrm{~h}^{-1}\right)$, station $\mathrm{A}$ for nitrite $\left(0.4 \mathrm{~mol} \mathrm{~m}^{-2} \mathrm{~h}^{-1}\right)$, station

3 A for ammonium $\left(39.7 \mathrm{~mol} \mathrm{~m}^{-2} \mathrm{~h}^{-1}\right)$ and station $\mathrm{D}$ for silicate $\left(109.0 \mathrm{~mol} \mathrm{~m}^{-2} \mathrm{~h}^{-1}\right)$

4 (Table 1). The average for the stratified waters at stations B-D showed that there was

5 a flux of nitrate, phosphate, ammonium and silicate to the BML from the sediment

6 and overall was dominated by silicate.

\subsection{Water column nutrient uptake rates}

For station A, with a well-mixed water column, the uptake rates of ammonium and nitrate showed a maximum at $5 \mathrm{~m}$ of 19.9 and $55 \mathrm{~mol} \mathrm{~m}^{-3} \mathrm{~h}^{-1}$ respectively (Table 2). For the remaining summer stratified stations (B-D) ammonium and nitrate uptake was highest for all stations in the surface waters at station B (45.2 and $294.4 \mathrm{~mol} \mathrm{~m}^{-3} \mathrm{~h}^{-1}$, respectively). Average uptake rates for the layers of the stratified water column showed ammonium uptake dominated in the upper mixed layer and bottom mixed

\section{Discussion}

\subsection{Weather pattern and water column structure}

The summer period of 2003 was characterised by calm and warm weather with sea surface temperature in the Oyster Grounds an average of $2.7^{\circ} \mathrm{C}$ warmer for June August than the mean for the 1969 - 1993 (Bundesamt für Seeschifffahrt und Hydrographie; http://www.bsh.de/en). The water column physical structure reflected these conditions with moderate surface cooling and wind mixing resulting in strong temperature gradients in the thermocline (Fig. 3; sections a and b). In combination

28 with the presence of sharp horizontal and vertical density gradients around the Oyster

29 Grounds (Fig. 3), this resulted in an isolated bottom mixed layer not influenced by

30 Channel Water or CCW. As a result of its offshore location, anthropogenic nutrient

31 inputs to the Oyster Grounds will also be lower than in other coastal regions (Fig. 2).

32 The nutrient concentrations are therefore broadly set at the onset of stratification

33 although sedimentary processes lead to a flux of regenerated nutrients (Table 1). 
1 The stratified period ends with the break down of stratification generally occurring in

2 4 2003).

5

6

7

early October, due to the combination of advective overturning from cooling (Tijssen and Wetsteyn, 1984) and storm events generating inertial motion (van Haren et al.,

\subsection{Sedimentary processes}

The situation of the Oyster Grounds as a temporal depocentre results in this region playing an important role in biogeochemical cycling of carbon and nitrogen. Nitrate and ammonium sedimentary flux rates were similar to a previous study in the Oyster Grounds which measured positive fluxes of $13 \pm 9$ and $14 \pm 10 \mathrm{~mol} \mathrm{~m}^{-2} \mathrm{~h}^{-1}$ respectively in August (Lohse et al., 1993). Although there are no recorded data for nitrite, phosphate and silicate fluxes in the Oyster Grounds region, measurements of nutrient fluxes for south western North Sea in October $\left(\mathrm{SiO}_{2} 0-\sim 30 \mathrm{~mol} \mathrm{~m}^{-2} \mathrm{~h}^{-1}\right.$ (Sanders et al., 2001)) and the Skaggerak between March - September $\left(\mathrm{NO}_{2}^{-}-0.9-0.2 \mathrm{~mol} \mathrm{~m}^{-2} \mathrm{~h}^{-}\right.$ ${ }^{1}$; $\mathrm{PO}_{4}^{-}-15.1-60.2 \mathrm{~mol} \mathrm{~m}^{-2} \mathrm{~h}^{-1}$; and $\mathrm{SiO}_{2}$ 0.0-0.16 $\mathrm{mol} \mathrm{m}^{-2} \mathrm{~h}^{-1}$ (Hall et al., 1996)) showed a similar range.

The relative ratios of sedimentary N:P:Si flux demonstrates that in terms of Redfield stoichiometry (Redfield et al., 1966) N was potentially limiting phytoplankton primary production as has been shown for other regions of the North Sea (Riegman et al., 1990). The silicate flux at all stations was considerably in excess of the equimolar Si and $\mathrm{N}$ considered to be necessary for diatom growth (Justic et al., 1995). It would also therefore be expected that there may be a different phytoplankton species composition in the BML and DCM in relation to the SML where silicate concentrations were low (Fig. 5).

The rates of denitrification (Table 1) were made before the introduction of a technique allowing the measurement of rates of both denitrification and anaerobic ammonium oxidation (anammox) (Trimmer et al., 2006). Anammox is significant in some coastal sediments (for review see Dalsgaard et al. (2005)) and in these regions, the use of the original isotope pairing technique of Nielsen (1992) can lead to an overestimation of denitrification rates (Risgaard-Petersen et al., 2003). Rates of denitrification reported here are therefore estimates of potential denitrification activity with rates in the expected range for continental shelf regions (Seitzinger and Giblin, 
1 1996) and similar to previous rate measurements in the Oyster Grounds in August of

$20.8 \mathrm{~mol} \mathrm{~m}^{-2} \mathrm{~h}^{-1}$ (Lohse et al., 1993) with denitrification in the Oyster Grounds

3 dominated by coupling with nitrification (Table 1 ).

4 The dominant denitrification pathway was coupled to the nitrification of porewater 5 ammonium, i.e. $\mathrm{D}_{\mathrm{n}}$, and therefore reduced potential ammonium flux. $\mathrm{D}_{\mathrm{n}}$ represents 6 only $18 \%$ of total dissolved inorganic nitrogen (DIN) mineralization (nitrate flux + 7 ammonium flux $+D_{n}$ ), which is low compared to the $D_{n}$ as a proportion of DIN reported for the western Irish Sea (63\%) (Trimmer et al., 1999). This is further complicated in that if significant anammox were present, these estimates of $D_{n}$ are likely to be overestimates (Trimmer et al., 2006) making $D_{n}$ as a proportion of DIN lower still. The nitrite produced due to this pathway is also expected to be removed from the water column due to the flux of nitrite into the sediments measured (Table $1)$.

Benthic oxygen consumption rates (Table 1) were typical for continental shelf regions (Seitzinger and Giblin, 1996), although they were at the lower range of values previously measured at the Frisian Front (van Raaphorst et al., 1990) which may be expected since the Frisian Front is a region of enhanced sedimentation and benthic production (van Raaphorst et al., 1992). It is this oxygen consumption which drives the low bottom oxygen levels measured in combination with a source of biomass input and stratification.

\subsection{Water column nutrient uptake rates}

Nitrate and ammonium uptake rates, for the whole water column, were in the range 0.2-45.2 and 2.2-249.4 $\mathrm{mol} \mathrm{m}^{-3} \mathrm{~h}^{-1}$ respectively (Table 2) and are in agreement with (Owens et al., 1990) who showed nitrate and ammonium uptake rates up to 80 and $100 \mathrm{~mol} \mathrm{~N} \mathrm{~m}^{-3} \mathrm{~h}^{-1}$ for surface waters in this region during July. The $f$ ratio is commonly used to compare these uptake rates of ammonium and nitrate (Eppley and Peterson, 1979) and gives an indication of the $\mathrm{N}$ uptake due to new production, i.e. due to allochthonous nitrate sources, relative to regenerated production (Table 2). The low $f$ ratios in the surface waters are in agreement with Weston et al. (2004) which showed $f$ ratios ranging from 0.07-0.51 for the well-mixed region of the southern North Sea for September. At the DCM, the average $f$ ratio of 0.58 was high compared 
1 to the average $f$ ratio of 0.35 at a similar DCM close to the Dogger Bank (Weston et

2 al., 2005). The $f$ ratio may be overestimated due to the omission of urea uptake measurements (Riegman and Noordeloos, 1998) and water column nitrification (Yool et al., 2007). Urea uptake is however not expected to significantly alter the overall trends of nitrogen assimilation (Weston et al., 2004). The effect of nitrification in the water column is difficult to quantify since there have been no measurements in the North Sea and a limited number worldwide (Yool et al., 2007).

The clarity of the water column, stratification and the removal of nutrients in the upper mixed layer (UML) results in the formation of a DCM at the thermocline and hence continued new production throughout the summer. In the BML, high water column ammonium uptake rates resulted from regenerated ammonium due to the remineralisation of organic matter as shown by the ammonium flux from the sediments (Table 1). By contrast, nitrate concentrations remained significantly higher in the BML, which may be due to phytoplankton ammonium uptake repressing the need for nitrate (Flynn, 1999). The regeneration of organic matter in the UML led to a similar situation as in the BML with the production of ammonium due to remineralisation of organic matter after the spring bloom leading to a dominance of phytoplankton ammonium uptake.

\subsection{Low bottom water dissolved oxygen and its causes}

The measured bottom water dissolved oxygen concentration of $2.07 \mathrm{mg} \mathrm{l}^{-1}$ in October 2003 in the centre of the Oyster Grounds was significantly lower than published values with oxygen minima of $\sim 6-7 \mathrm{mg}^{-1}$ in the BML in August 1976 (Postma and Rommets, 1984), $6.5 \mathrm{mg} \mathrm{l}^{-1}$ in summer 1988 and $\sim 4.5 \mathrm{mg}^{-1}$ in summer 1989 (Peeters et al., 1995) and $3.2 \mathrm{mg} \mathrm{l}^{-1}$ for September 2003 (Boers, 2005). These low BML oxygen concentrations indicate the potential for this region to develop hypoxia. In order for oxygen levels to decrease throughout the stratified period, as shown by Boers (2005), there must be suitable i) physical conditions, ii) biomass production, iii) nutrient input and iv) continued benthic oxygen consumption.

The occurrence of these conditions in the Oyster Grounds can be addressed as

follows: 
1 i) The water column structure (section 4.1) shows how the bottom mixed layer is

2 isolated by strong gradients in the thermocline limiting the diffusion of oxygen into

3 the bottom mixed layer. Water mass transfer along the seabed is prevented by bottom

4 fronts, which are evident as sharp density contours (Fig. 3). Additionally, tidal residuals are weak and do not act as a significant advective component (van Aken et

6 al., 1987).

7 ii) New biomass production, i.e. production that can be exported into the bottom layer,

8 has been shown to occur at the DCM by the high $f$ ratio and nitrate uptake rates.

9 Consequently there was continuing net primary production even at the end of the

10 stratified growing period with the magnitude of the DCM new production previously

11 estimated to be equal to that of the spring bloom in the stratified regions of the 12 northern North Sea (Weston et al., 2005). In contrast to the DCM new production, the

13 continuous low primary production in the BML will not alleviate low bottom water

14 oxygen concentrations measured, since the production of oxygen due to primary

15 production in the BML will be compensated by oxygen uptake during sedimentary

16 remineralisation (Peeters et al., 1995).

17 iii) In order for the new production to occur, new (allochthonous) nutrients must drive

18 the production in the DCM. Nutrient input however has been shown to be provided

19 from sedimentary remineralisation with denitrification supported by nitrate uptake

20 (Av $\mathrm{D}_{\mathrm{w}} 0.16 \mathrm{~mol} \mathrm{~m}^{-2} \mathrm{~h}^{-1}$ for BML nitrate) an order of magnitude less than the flux of

21 nitrate from the sediments therefore resulting in net nitrate flux. This flux would

22 therefore have supported the high nitrate in the BML (Fig. 5) and result in regenerated

23 production in the DCM. This flux would however be unable to fully support the

24 nitrate uptake rates measured in the DCM since nitrate uptake at the DCM averaged

$2535 \mathrm{~mol} \mathrm{~m}^{-3} \mathrm{~h}^{-1}$ and nitrate flux was $4.5 \mathrm{~mol} \mathrm{~m}^{-2} \mathrm{~h}^{-1}$ into the BML for the stratified

26 stations. A significant proportion of the nitrate driven production at the DCM was

27 therefore new production which would result in oxygen consumption in the

28 sediments. Potential new $\mathrm{N}$ inputs due to atmospheric deposition would also drive

29 new production and potential new biomass input into the bottom waters but this

30 production would occur in the upper mixed layer (Spokes et al., 1993). These

31 atmospheric inputs would therefore not be expected to affect nitrate uptake rates in the

32 DCM. 
1 iv) The significant measured rate of sedimentary oxygen consumption was expected

2 to be due to a recent input of 'new' organic matter to the sediments during the

3 stratified period, since a study in the western Irish Sea gyre (Trimmer et al., 1999)

4 showed that the impact of the spring bloom on benthic oxygen uptake only lasts a few

5 weeks. The remineralisation of this biomass will drive decreasing oxygen

6 concentrations in the BML long after the spring bloom, as was shown previously with

7 bottom water oxygen concentrations decreasing steadily to a minimum of $3.2 \mathrm{mg} \mathrm{l}^{-1}$

8 throughout the stratified period ( March - September) at the Oyster Grounds (Boers,

9 2005).

11 The continued new production in the thermocline at the DCM should therefore be 12 considered to be a significant driver of low oxygen bottom water concentrations in 13 this region. Although daily primary production in the DCM is low relative to the 14 spring bloom, the DCM occurs throughout the stratified period and can be expected to 15 have a similar magnitude of impact as the spring bloom on bottom oxygen levels.

\subsection{Consequences of low oxygen levels in the Oyster Grounds}

There have been a limited number of studies on low oxygen levels in the offshore North Sea as outlined in Colijn et al. (2002). In addition, there have been no studies on the ecosystem effects on the low oxygen concentrations in this region to the best of our knowledge and this study has made no attempt to address this issue. This area is however an important feeding ground for many demersal fish such as sole (Solea solea) and plaice (Pleuronectes platessa), which are known to be affected by low oxygen concentrations $\left(<3 \mathrm{mg} \mathrm{l}^{-1}\right)$ (Tyson and Pearson, 1991). While it is possible that fish can employ avoidance tactics, relatively immobile shellfish and benthic fauna may be impacted. For example, Nephrops norvegicus can be sensitive to water

28 column hypoxia, while adults can cope with a wide range of environmental variation (except when hypoxic), the effect on juveniles is marked at relatively mild levels of oxygen depletion $\left(<5 \mathrm{mg} \mathrm{l}^{-1}\right.$ ) (Baden et al., 1990). The benthic community composition in the Oyster Grounds is likely to change if there are repeated large scale low oxygen events.

33 Current climate change scenarios for the North Sea may also act to decrease bottom 34 water dissolved oxygen in this region in the future due to three main predicted 
1 features: waters will be warmer by $2-3^{\circ} \mathrm{C}$ and therefore contain less dissolved oxygen

2 by $0.4 \mathrm{mg}^{-1}$; stratification will occur earlier, the period of stratification longer and of

3 greater geographic extent since the surface waters will warm up preferentially, and

4 summer storms will decrease (Hulme et al., 2002). The increase in stratification

5 period may therefore in turn increase the annual new production possible at the DCM

6 with the subsequent potential impacts on bottom water oxygen levels indicated by our

7 findings.

\section{Conclusion}

11 The Oyster Grounds region shows potential for low bottom oxygen levels due to the isolation of a shallow bottom mixed layer and the remineralisation of the organic matter produced during the spring bloom and also subsequently from new production throughout the summer at the DCM until stratification breakdown. The offshore regions of the North Sea are undersampled both in terms of addressing the extent of low oxygen levels and also the relevant biogeochemical processes. There is therefore

17 a need for improved monitoring in such regions to determine the location and 18 development of low oxygen concentrations, and if necessary, its impact on the benthos.

\section{Acknowledgements}

This work was funded by Defra as a part of the AE1225 project. We would like to thank Dr Naomi Greenwood and Olga Andres (CEFAS) for the nutrient and oxygen analyses and the officers and crew of R/V Endeavour for their assistance in this work.

26 We also thank two anonymous referees whose recommendations improved this manuscript.

\section{References}


1 between the Southern Bight and Oyster Grounds. NIOZ report, Texel, The

2 Netherlands, $56 \mathrm{p}$.

3 Baden, S. P., Loo, L. O., Pihl, L., Rosenberg, R., 1990. Effects of eutrophication on

4 benthic communities including fish: Swedish west coast. Ambio, 19, 113-122.

5 Boers, M., 2005. Effects of a deep sand extraction pit. Final report of the PUTMOR

6 measurements at the Lowered Dump Site. Report reference number RIKZ / 2005.001,

$7 \quad$ Rijkswaterstaat, The Netherlands, $87 \mathrm{p}$.

8 Brown, J., Brander, K. M., Fernand, L., Hill, A. E., 1996. Scanfish: a high

9 performance towed undulator. Sea Technology, 37, 23-27.

10 Colijn, F., Hesse, K.-J., Ladwig, N., Tillmann, U., 2002. Effects of the large-scale

11 controlled fertilisation process along the continental coastal North Sea.

12 Hydrobiologia, 484, 133-148.

13 Conley, D. J., Humborg, C., Rahm, L., Savchuk, O. P., Wulff, F., 2002. Hypoxia in

14 the Baltic Sea and basin-scale changes in phosphorus biogeochemistry.

15 Environmental Science and Technology, 36, 5315-5320.

16 Cook, R. M., Sinclair, A., Staffanson, G., 1997. Potential collapse of North Sea cod

17 stocks. Nature, 385, 521-522.

18 Dalsgaard, T., Thamdrup, B., Canfield, D. E., 2005. Anaerobic ammonium oxidation

19 (anammox) in the marine environment. Research in Microbiology, 156, 457- 464.

20 Diaz, R. J., 2001. Overview of hypoxia around the World. Journal of Environmental

21 Quality, 30, 275-281.

22 Dugdale, R. C., Goering, J. J., 1967. Uptake of new and regenerated forms of nitrogen

23 in primary productivity. Limnology and Oceanography, 12, 196-206.

24 Eppley, R. W., Peterson, B. J., 1979. Particulate organic matter flux and planktonic 25 new production in the deep ocean. Nature, 282, 677-680. 
1 Flynn, K. J., 1999. Nitrate transport and ammonium-nitrate interactions at high nitrate

2 concentrations and low temperatures. Marine Ecology Progress Series, 187, 283-287.

3 Hall, P. O. J., Hulth, S., Hulthe, G., Landen, A., Tengberg, A., 1996. Benthic nutrient

4 fluxes on a basin-wide scale in the Skaggerak (North-eastern North Sea). Journal of

$5 \quad$ Sea Research, 35, 123-137.

6 Hill, H.W., 1971. Currents and water masses. In: Goldberg, E.D. (Ed.), North Sea

7 Science. MIT press, Cambridge, pp. 17-42

8 Holmes, R. M., Aminot, A., Kérouel, R., Hooker, B. A., Peterson, B. J., 1999. A

9 simple and precise method for measuring ammonium in marine and fresh water

10 ecosystems. Canadian Journal of Fisheries and Aquatic Sciences, 56, 1801-1808.

11 Hulme, M., Jenkins, G. J., Lu, X., Turnpenny, J. R., Mitchell, T. D., Jones, R. G.,

12 Lowe, J., Murphy, J. M., Hassell, D., Boorman, P., McDonald, R., Hill, S., 2002.

13 Climate Change Scenarios for the United Kingdom: The UKCIP02 Scientific Report.

14 Tyndall Centre for Climate Change Research, School of Environmental Sciences,

15 University of East Anglia, 120 p.

16 Justic, D., Rabalais, N. N., Turner, R. E., Dortch, Q., 1995. Changes in nutrient

17 structure of river-dominated coastal waters: Stoichiometric nutrient balance and its

18 consequences. Estuarine, Coastal and Shelf Science, 40, 339-356.

19 Kirkwood, D. S., 1996. Nutrients: Practical notes on their determination in seawater.

20 ICES Techniques in Marine Environmental Sciences, no 17. International Council for

21 the Exploration of the Seas, Copenhagen, $23 \mathrm{p}$.

22 Lohse, L., Malschaert, H., Slomp, C. P., Helder, W., van Raaphorst, W., 1993.

23 Nitrogen cycling in North Sea sediments: interaction of denitrification and

24 nitrification in offshore and coastal areas. Marine Ecology Progress Series, 101, 28325296. 
1 Mee, L. D., 1992. The Black Sea in crisis: a need for concerted international action.

2 Ambio, 21, 278-286.

3 Nedwell, D., Trimmer, M., 1996. Nitrogen fluxes through the upper estuary of the

4 Great Ouse, England: the role of the bottom sediments. Marine Ecology Progress

5 Series, 142, 273-286.

6 Nielsen, L. P., 1992. Denitrification in sediment determined from nitrogen isotope

7 pairing. FEMS Microbiological Ecology, 86, 357-362.

8 Owens, N. J. P., Woodward, E. M. S., Aiken, J., Bellan, I. E., Rees, A. P., 1990.

9 Primary production and nitrogen assimilation in the North Sea during July 1987.

10 Netherlands Journal of Sea Research, 25, 143-154.

11 Peeters, J. C. H., Los, F. J., Jansen, R., Haas, H. A., Peperzak, L., de Vries, I., 1995.

12 The oxygen dynamics of the Oyster Ground, North Sea. Impact of eutrophication and

13 environmental conditions. Ophelia, 42, 257-288.

14 Peperzak, L., 2003. Climate change and harmful algal blooms in the North Sea. Acta

15 Oecologica, 24, 139-144.

16 Pingree, R. D., Holligan, P. M., Mardell, G. T., 1978. The effects of vertical stability

17 on phytoplankton distributions in the summer on the northwest European Shelf. Deep-

18 Sea Research, 25, 1011-1028.

19 Postma, H., Rommets, J. W., 1984. Variations of particulate organic carbon in the

20 central southern North Sea. Netherlands Journal of Sea Research, 18, 31-50.

21 Rabalais, N. N., Turner, R. E., Wiseman, W. J., 2002. Gulf of Mexico hypoxia, aka

22 "The dead zone". Annual Review of Ecology and Systematics, 33, 235-263.

23 Redfield, A. C., Ketchum, B. H., Richard, F. A., 1966. The influence of organisms on

24 the composition of sea-water. In: Hill, M.N. (Ed.), The sea, volume 2. Interscience, 25 Eire, pp. 26-77. 
1 Riegman, R., Colijn, F., Malschaert, J. F. P., Kloosterhuis, H. T., Cadée, G. C., 1990.

2 Assessment of growth rate limiting nutrients in the North Sea by the use of nutrient-

3 uptake kinetics. Netherlands Journal of Sea Research, 26, 53-60.

4 Riegman, R., Noordeloos, A. A. M., 1998. Size-fractionated uptake of nitrogenous

5 nutrients and carbon by phytoplankton in the North Sea during summer 1994. Marine

6 Ecology Progress Series, 173, 95-106.

7 Risgaard-Petersen, N., Nielsen, L. P., Rysgaard, S., Dalsgaard, T., Meyer, R. L., 2003.

8 Application of the isotope pairing technique in sediments were anammox and

9 denitrification coexist. Limnology \& Oceanography Methods, 1, 63-73.

10 Ryther, J. H., Dunstan, W. M., 1971. Nitrogen, phosphorus and eutrophication in the

11 coastal marine environment. Science, 171, 1008-1013.

12 Sanders, R., Jickells, T., Mills, D., 2001. Nutrients and chlorophyll at two sites in the

13 Thames plume and southern North Sea. Journal of Sea Research, 46, 13-28.

14 Seitzinger, S. P., Giblin, A. E., 1996. Estimating denitrification in North Atlantic

15 continental shelf sediments. Biogeochemistry, 35, 235-260.

16 Spokes, L., Jickells, T., Rendell, A., Schulz, M., Rebers, A., Dannecker, W., Kruger,

17 O., Leermakers, M., Baeyens, W., 1993. High atmospheric deposition events over the

18 North Sea. Marine Pollution Bulletin, 26, 698-703.

19 Tett, P. (1987). Plankton. In: Baker J. M., Wolff, J.W. (Eds.), Biological surveys of

20 estuaries and coasts. Cambridge University Press, Cambridge, pp. 280-341.

21 Tijssen, S. B., Wetsteyn, F. J., 1984. Hydrographic observations near a subsurface

22 drifter in the Oyster Ground, North Sea. Netherlands Journal of Sea Research, 18, 13 $23 \quad 30$. 
1 Trimmer, M., Gowen, R. J., Stewart, B. M., Nedwell, D. B., 1999. The spring bloom

2 and its impact on benthic mineralisation rates in western Irish Sea sediments. Marine

3 Ecology Progress Series, 185, 37-46.

4 Trimmer, M., Risgaard-Petersen, N., Nicholls, J. C., Engström, P., 2006. Direct

5 measurement of anaerobic ammonium oxidation (anammox) and denitrification in

6 intact sediment cores. Marine Ecology Progress Series, 326, 37-47.

7 Tyson, R. V., Pearson, T. H., 1991. Modern and ancient continental shelf anoxia: an

8 overview. In: Tyson R.V., Pearson, T.H. (Eds.), Modern and ancient continental shelf

9 anoxia. Geological Society, London, pp. 1-24.

10 UNESCO 1981. Background papers and supporting data on the Practical Salinity

11 Scale, 1978. UNESCO Technical Papers in Marine Science No. 37. UNESCO,

12 Geneva, $144 \mathrm{pp}$.

13 van Aken, H. M., van Heijst, G. J. F., Maas, L. R. M., 1987. Observations of fronts in

14 the North Sea. Journal of Marine Research, 45, 579-600.

15 van Haren, H., Howarth, M. J., Jones, K., Ezzi, I., 2003. Autumnal reduction of

16 stratification in the northern North Sea and its impact. Continental Shelf Research, 23, $17 \quad 177-191$.

18 van Raaphorst, W., Kloosterhuis, H. T., Berghuis, E. M., Gieles, A. J. M., Malschaert,

19 J. F. P., Noort, G. J. V., 1992. Nitrogen cycling in two types of sediments of the

20 southern North Sea (Frisian Front, Broad Fourteens): Field data and mesocosm

21 results. Netherlands Journal of Sea Research, 28, 293-316.

22 van Raaphorst, W., Kloosterhuis, H. T., Cramer, A., Bakker, K. J. M., 1990. Nutrient

23 early diagenesis in the sandy sediments of the Dogger Bank area, North Sea: pore

24 water results. Netherlands Journal of Sea Research, 26, 25-52. 
1 van Raaphorst, W., Malschaert, H., van Haren, H., 1998. Tidal resuspension and

2 deposition of particulate matter in the Oyster Grounds, North Sea. Journal of Marine

3 Research, 56, 257-291.

4 Weston, K., Jickells, T. D., Fernand, L., Parker, E. R., 2004. Nitrogen Cycling in the

5 Southern North Sea: Consequences for Total Nitrogen Transport. Estuarine, Coastal

6 and Shelf Science, 59, 559-573.

7 Weston, K., Fernand, L., Mills, D. K., Delahunty, R., Brown, J., 2005. Primary

8 production in the deep chlorophyll maximum of the central North Sea. Journal of

$9 \quad$ Plankton Research, 27, 909-922.

10 Williams, P. J. le B., Jenkinson, N., 1982. A transportable microprocessor-controlled

11 precise Winkler titration suitable for field station and shipboard use. Limnology and

12 Oceanography, 27, 576-584.

13 Yool, A., Martin, A., P., Fernandez, C., Clark, D. R., 2007. The significance of

14 nitrification for oceanic new production. Nature, 447, 999-1002.

15 
Table 1

2 Sediment nutrient exchange rates $( \pm S E ; n=3)$ and sedimentary oxygen uptake $( \pm S E ; n=3)$ and denitrification $( \pm S E ; n=4)$ where $D_{w}$ is

3 denitrification supported by the uptake of nitrate from the overlying water and $\mathrm{D}_{\mathrm{n}}$ is denitrification coupled to nitrification of porewater

4 ammonium. All measurements are $\mathrm{mol} \mathrm{m}^{-2} \mathrm{~h}^{-1}$ and were made at bottom water temperature. For nutrient exchange rates, positive values indicate

5 flux from sediment to water and negative values indicate from water to sediment. Average calculated for bottom mixed layer for station B-D

6 (Station A was well-mixed). ${ }^{*}$ For N:P:Si ratio $\mathrm{N}^{\text {tot }}=\mathrm{NO}_{3}{ }^{-}+\mathrm{NO}_{2}{ }^{-}+\mathrm{NH}_{4}{ }^{+}$flux

\begin{tabular}{llllllllll}
\hline $\mathrm{Stn}$ & $\mathrm{NO}_{3}^{-}$ & $\mathrm{NO}_{2}^{-}$ & $\mathrm{NH}_{4}^{+}$ & $\mathrm{PO}_{4}^{-}$ & $\mathrm{SiO}_{2}$ & $* \mathrm{~N}^{\text {tot. }}: \mathrm{Si}$ & $\mathrm{O}_{2}$ uptake & $\mathrm{D}_{\mathrm{n}}$ & $\mathrm{D}_{\mathrm{w}}$ \\
& & & & & & & & & \\
\hline $\mathrm{A}$ & 4.0 & 0.4 & 39.7 & 0.8 & 92.6 & $55.1: 1: 115.6$ & 524.3 & 2.7 & 0.8 \\
& $( \pm 2.0)$ & $( \pm 0.1)$ & $( \pm 8.8)$ & $( \pm 0.8)$ & $( \pm 16.7)$ & & $( \pm 63.4)$ & $( \pm 0.7)$ & $( \pm 0.2)$ \\
$\mathrm{B}$ & 0.0 & -7.7 & 11.4 & 2.9 & 58.9 & $1.3: 1: 20.3$ & 996.5 & 3.4 & 0.15 \\
& $( \pm 0.0)$ & $( \pm 0.2)$ & $( \pm 4.1)$ & $( \pm 1.2)$ & $( \pm 10.2)$ & & $( \pm 200.3)$ & $( \pm 1.0)$ & $( \pm 0.1)$ \\
$\mathrm{C}$ & 7.9 & -3.0 & -4.2 & 1.0 & 38.6 & $0.7: 1: 38.6$ & 782.1 & 2.6 & 0.07 \\
& $( \pm 2.1)$ & $( \pm 0.2)$ & $( \pm 5.3)$ & $( \pm 0.8)$ & $( \pm 6.8)$ & & $( \pm 152.6)$ & $( \pm 0.5)$ & $( \pm 0.0)$ \\
$\mathrm{D}$ & 5.6 & -2.5 & 18.0 & 3.0 & 109.0 & $7.0: 1: 36.3$ & 1275.1 & 2.8 & 0.26 \\
& $( \pm 1.3)$ & $( \pm 0.1)$ & $( \pm 6.7)$ & $( \pm 0.7)$ & $( \pm 15.0)$ & & $( \pm 43.2)$ & $( \pm 0.6)$ & $( \pm 0.1)$ \\
$\mathrm{Av}$ & 4.5 & -4.4 & 8.4 & 2.3 & 68.8 & $3.7: 1: 29.9$ & 1017.9 & 2.9 & 0.16 \\
\hline
\end{tabular}




\section{ACCEPTED MANUSCRIPT}

Table 2

Nitrate and ammonium uptake rates for stations A-D and $f$ ratio for stations A-D where $f-\rho \mathrm{NO}_{3}{ }^{-} /\left(\rho \mathrm{NO}_{3}{ }^{-}+\rho \mathrm{NH}_{4}{ }^{+}\right)$where $\rho-$ uptake rate. Layers are well-mixed (WM, no stratification), surface of upper mixed layer (Surface), mid-upper mixed layer (UML), deep chlorophyll maximum (DCM) and bottom mixed layer (BML).

\begin{tabular}{|c|c|c|c|c|c|c|c|}
\hline Station & Depth & Layer & $\begin{array}{l}\mathrm{NO}_{3}^{-} \text {uptake } \\
/ \mathrm{mol} \mathrm{m}^{-3} \mathrm{~h}^{-1}\end{array}$ & $\begin{array}{c}\mathrm{SE} \\
(\mathrm{n}-3)\end{array}$ & $\begin{array}{l}\mathrm{NH}_{4}^{+} \text {uptake / } \\
\text { umol } \mathrm{m}^{-3} \mathrm{~h}^{-1}\end{array}$ & $\begin{array}{c}\mathrm{SE} \\
(\mathrm{n}-3)\end{array}$ & $f$ ratio \\
\hline \multirow[t]{4}{*}{$\mathrm{A}$} & $\overline{0}$ & WM & 7.7 & 2.3 & 11.4 & 1.0 & 0.40 \\
\hline & 5 & WM & 55 & 7.9 & 19.9 & 0.1 & 0.73 \\
\hline & 15 & WM & 0.2 & 0.4 & 2.5 & 3.1 & 0.07 \\
\hline & 36 & WM & 4.3 & 2.2 & 13.7 & 4.0 & 0.24 \\
\hline \multirow[t]{4}{*}{ B } & 0 & Surface & 45.2 & 13.6 & 249.4 & 15.0 & 0.15 \\
\hline & 15 & UML & 22.7 & 2.7 & 118.6 & 14.9 & 0.16 \\
\hline & 34 & DCM & 32.0 & 2.5 & 30.0 & 0.9 & 0.51 \\
\hline & 43 & BML & 6.4 & 2.8 & 25.1 & 7.1 & 0.20 \\
\hline \multirow[t]{3}{*}{$\mathrm{C}$} & 0 & Surface & 2.6 & 0.9 & 4.2 & 0.1 & 0.38 \\
\hline & 15 & UML & 1.3 & 0.2 & 11.9 & 1.7 & 0.09 \\
\hline & 35 & $\mathrm{DCM}$ & 44.1 & 10.5 & 15.7 & 1.8 & 0.73 \\
\hline \multirow[t]{9}{*}{$\mathrm{D}$} & 0 & Surface & 40.7 & 3.6 & 120.0 & 13.0 & 0.25 \\
\hline & 15 & UML & 2.3 & 0.3 & 2.2 & 3.0 & 0.51 \\
\hline & 29 & DCM & 28.9 & 2.1 & 28.0 & 7.0 & 0.51 \\
\hline & 44 & BML & 4.5 & 2.5 & 16.0 & 7.0 & 0.22 \\
\hline & & $\begin{array}{l}\text { Average } \\
\text { surface }\end{array}$ & & & & & \\
\hline & & \& UML & 19.1 & & 84.4 & & 0.18 \\
\hline & & DCM & 35.0 & & 24.6 & & 0.58 \\
\hline & & Average & & & & & \\
\hline & & BML & 5.5 & & 18.9 & & 0.23 \\
\hline
\end{tabular}




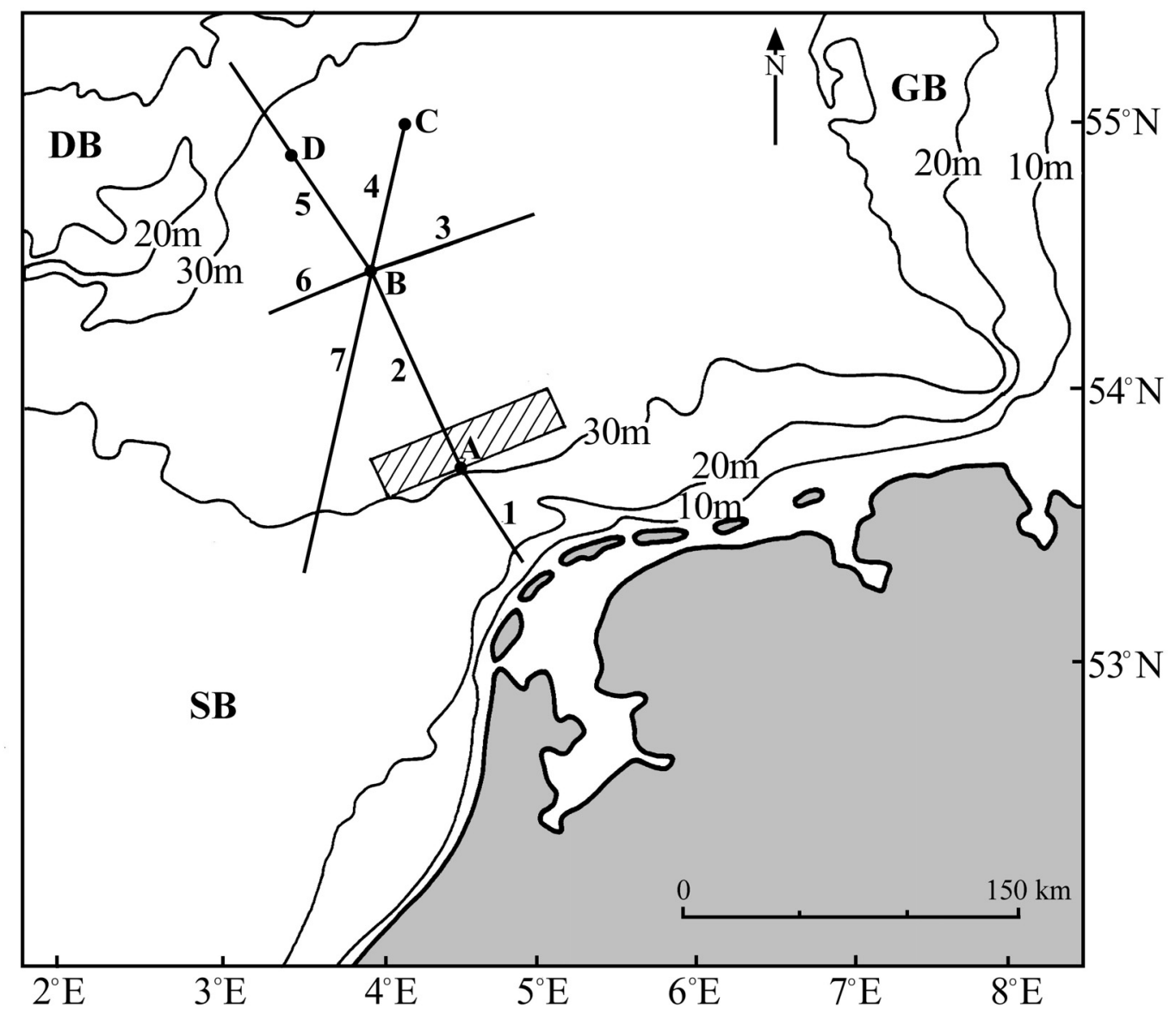

$1 \quad$ Fig. 1 


\section{ACCEPTED MANUSCRIPT}

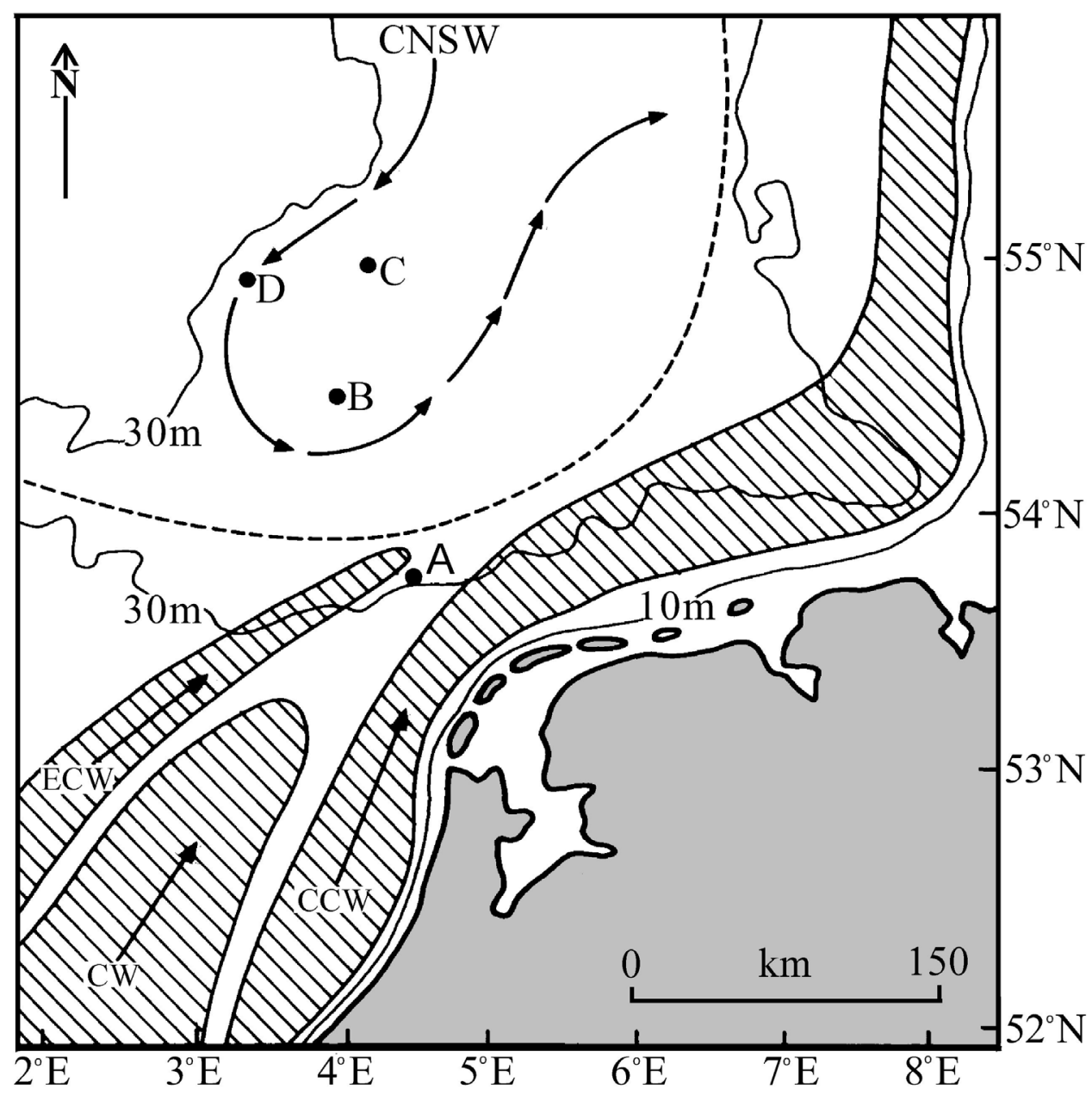

1 Fig. 2 

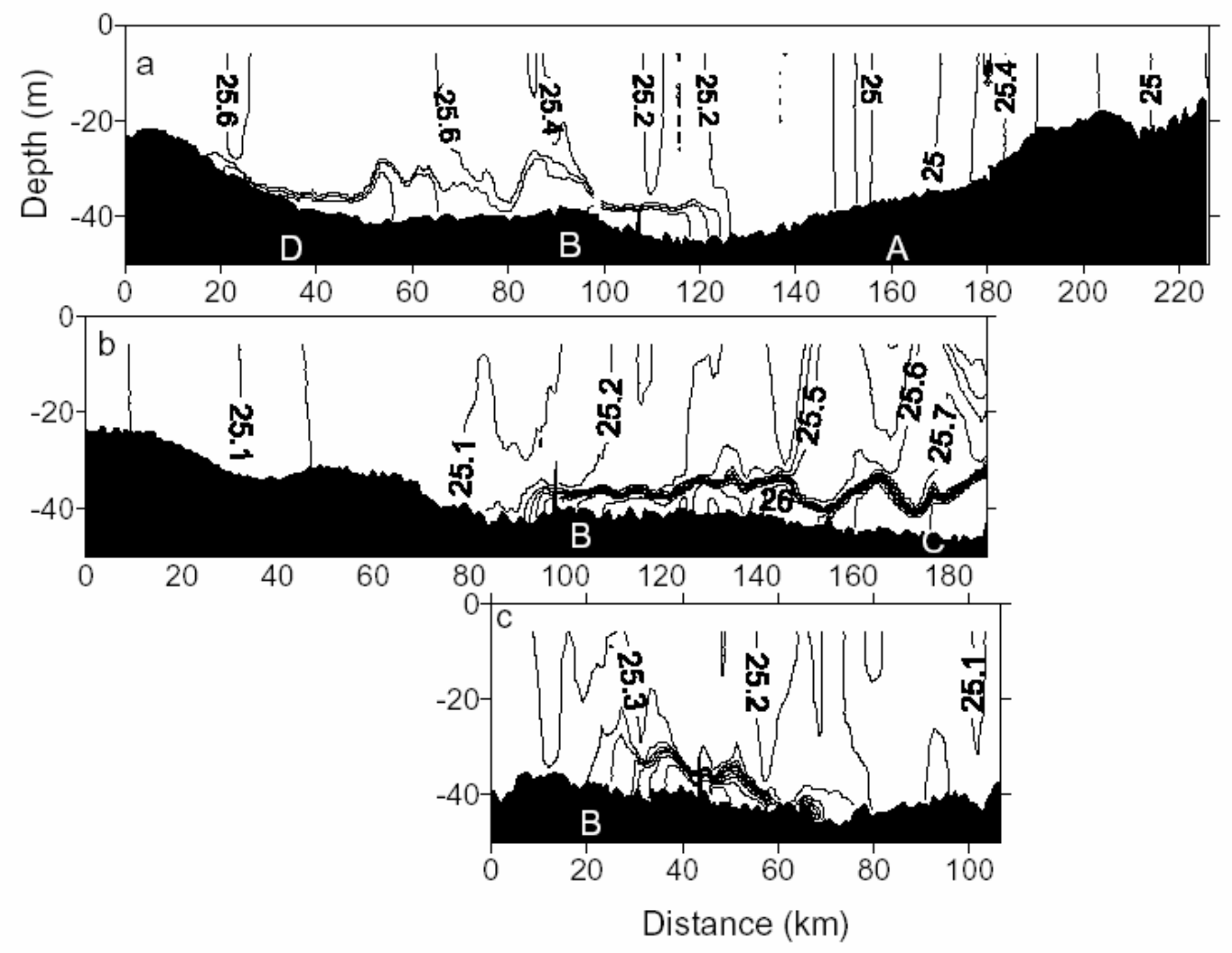

1

$2 \quad$ Fig. 3 


\section{ACCEPTED MANUSCRIPT}

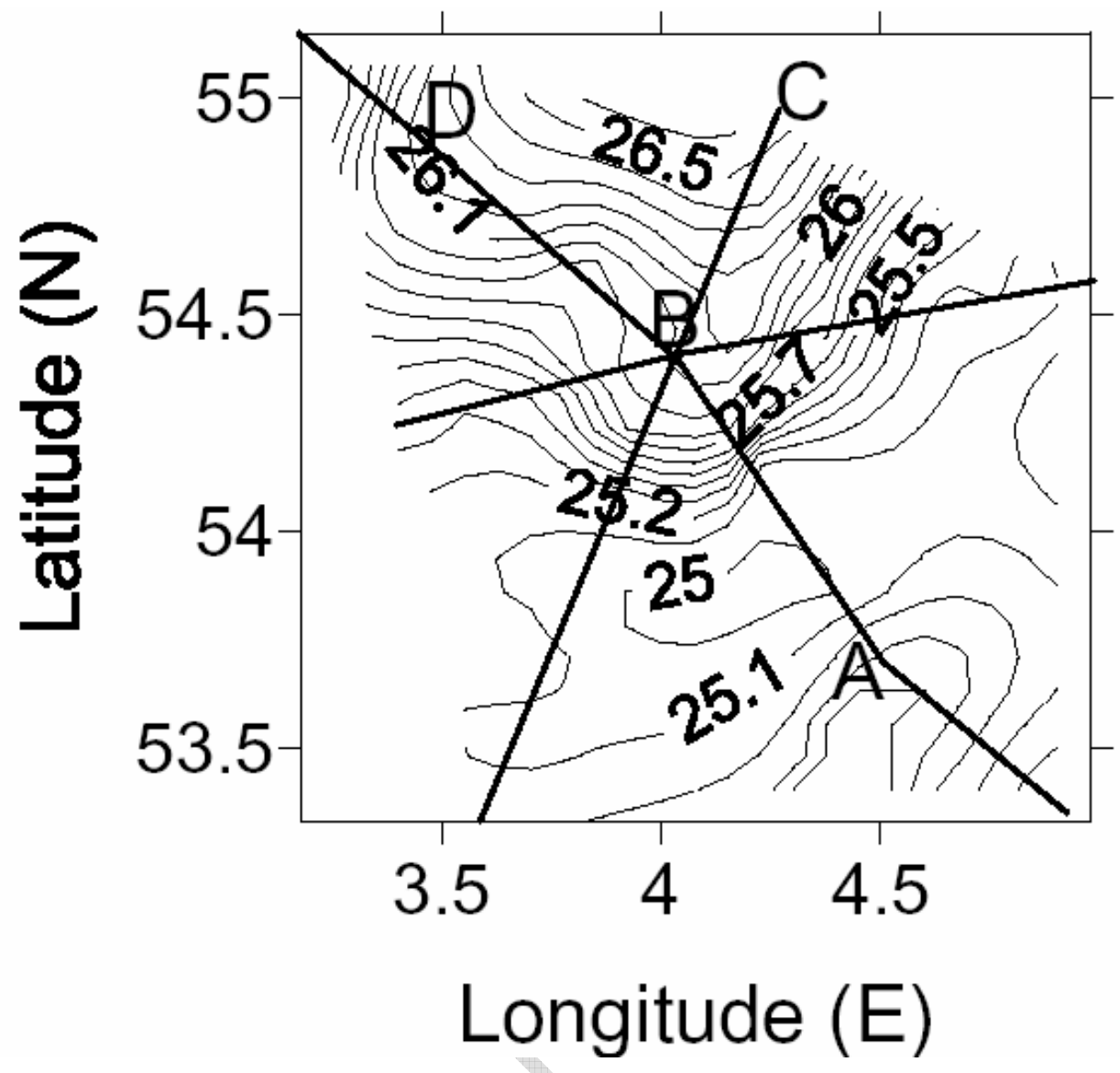

$2 \quad$ Fig.4 

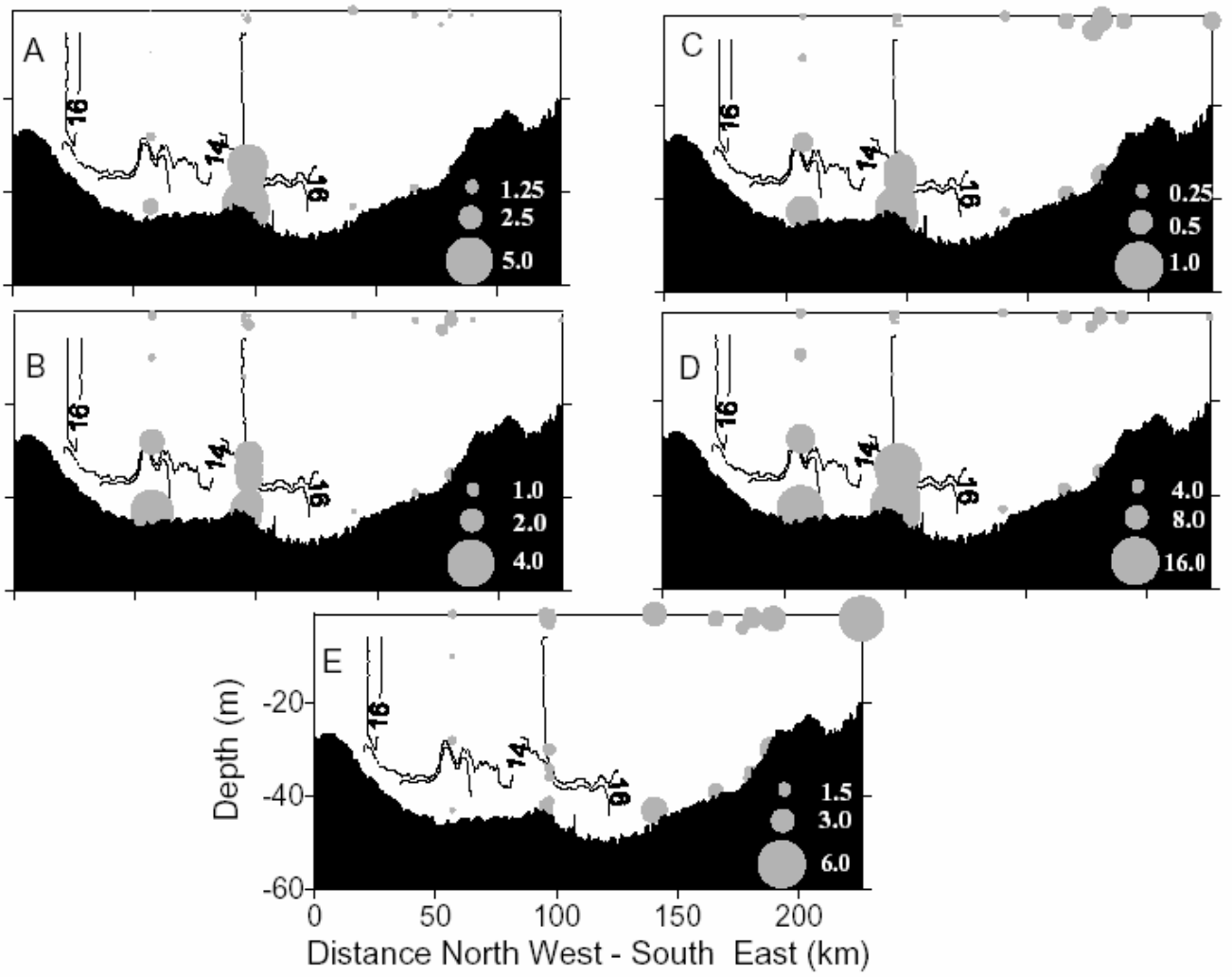

1

$2 \quad$ Fig. 5

3

4 